Saša Redžić

UDK: 904:739.1"652"(497.11)

Archaeological Institute Belgrade

ID BROJ: 196125452

sasa.redzic@gmail.com

Ilija Danković

Archaeological Institute Belgrade

Original research article

Received: July 08, 2011

Accepted: September 05, 2011

\title{
FIND OF A RARE TYPE OF ROMAN BELT SETS ON THE TERRITORY OF SERBIA
}

\begin{abstract}
Belt-set consisting of a square brlt-buckle and a button with a spherical head and a flat foot, that has no parallels within modern-day Serbia, was unearthed on Viminacium "Više Grobalja" necropolis. Similar finds are known from the different parts of the Roman Empire, mostly concentrating along the Raetian Limes. Common opinion is that these belt-sets were used by Roman soldiers, so one could suppose that this particular specimen reached Viminacium when troups were transferred from the Raetian Limes.
\end{abstract}

KEY WORDS: VIMINACIUM, BELT SET, BELT-BUCKLE, BUTTON.

During archaeological research of the Viminacium necropolis "Više grobalja", a belt set characterized by a square belt-buckle was discovered. It has no parallels on the territory of our country, according to authors' knowledge. ${ }^{1}$ Apart from the already mentioned belt-buckle, made of a copper alloy, the set also consists of a button made of the same material. The length of the edge of the belt-buckle is $4,7 \mathrm{~cm}$, while the button measures $2,3 \mathrm{~cm}$ in its diameter and $1,8 \mathrm{~cm}$ in its height. The belt-buckle was made in the opus interrasile

1 The set was noted in the field documentation under the number $\mathrm{C}-6870 / 1$, discovered in a cremation grave $\mathrm{G}_{1}-$ 956.

* The article results from the project: IRS - Viminacium, Roman city and legionary camp - research of material and non material culture of inhabitants by using modern technologies of remote sensing, geophysics, GIS, digitalisation and 3D visualisation (no 47018), funded by Ministry of Education, Science and Technological Development of the Republic of Serbia. style. In this way a square frame was formed, later decorated by faceting from the flat middle area decorated with vaults. This middle part, made narrow in the middle resembling a sand-clock, adittionally strengthens the belt-buckle. The set also contains a button with a spherical head and a flat, which was used for fitting of the belt.

In German literature, this type of buckles called Rehmenschnallencingulum, is usually found together with two buttons similar to ours. The belt-set we are dealing here with was fitted by putting the perforated ends of the strap through the belt-buckle and then onto the buttons like shown on figure 2. Second button is missing, and it might 

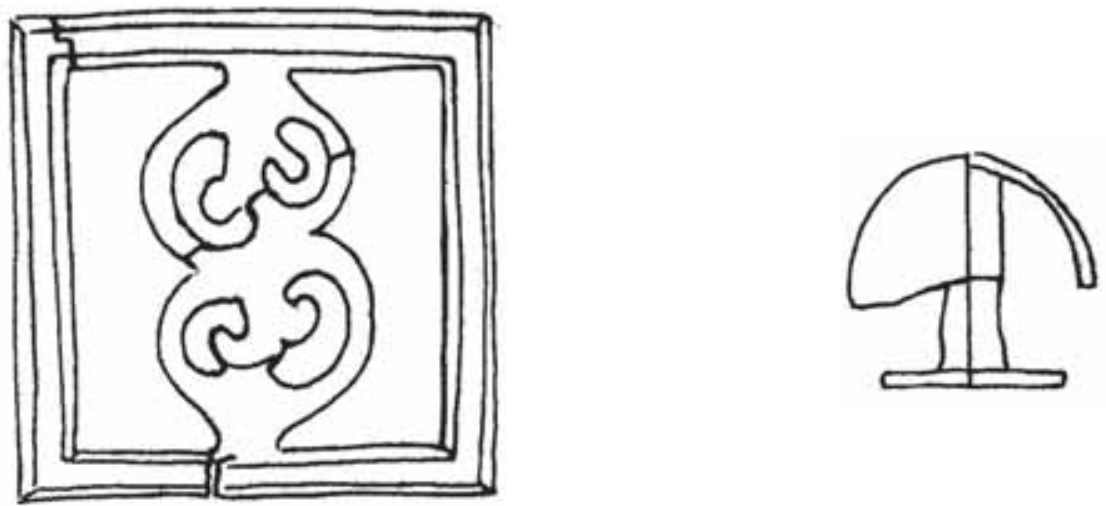

F.igure 1. Square belt-bucke with button

have been lost while the cremated remains were transferred from the stake into the grave. In the case that the belt-set originally possessed only one button, one could assume that one part of the strap was permanently connected to the buckle by sewing the strap instead of using the button.

Our specimen was made of a copper alloy, just like the similar example from the Romanian site Bruiu, discovered together with belt-buckles of the VTERE FELIX type and dated into the middle of the $3^{\text {rd }}$ century. ${ }^{2}$ Another belt-buckle of similar shape origins from Risnov, also in Romania. ${ }^{3} \mathrm{~J}$. Oldenstein describes belt-buckles of this type from the sites Osterburken, Pfünz, Faimingen, Karpova, Karlisla, Richborough, Linz and Intercisa, out of which the first two examples are identical to our belt-buckle. This author dates the buckles into the first half of the $3^{\text {rd }}$ century. ${ }^{4}$ During the research of the Regensburg necropolis, several belt-buckles of this type were discovered. Three examples, from graves nr. 284, 703 and 817, are identical to ours. The buckle from grave nr. 284 was discovered together with Galienus' coin, because of which the author S. Schnurbein dated this type from the end on the $2^{\text {nd }}$ until the second third of the $3^{\text {rd }}$ century. ${ }^{5}$ A buckle parallel to ours was discovered in Morocco, at the site Banasa. ${ }^{6}$ T. Fischer mentiones

2 Petculescu 1995,119-120, pl. 3, 1.

3 Petculescu 1995,119.

4 Oldenstein 1976, 222-223, Tafel 82, 1083-1086.

5 Schnurbein 1977, 87-88

6 Boube-Piccot 1994, Pl. 9/84. similar but probably slightly younger, luxuriously decorated silver buckles, which were parts of beltsets discovered in graves in Budapest and Silistra. Such examples were fitted with long buttons, very different from ours. The example from Budapest was found with several coins out of which, the youngest one was minted in 287, during Diocletian's reign. ${ }^{7}$ The Silistra find was dated with the coin of Probus. ${ }^{8}$ According to the facts listed above, we can see that this type of belt-buckles was probably used from the end of the $2^{\text {nd }}$ century until the end of the $3^{\text {rd }}$ century. Since our set was discovered in a cremated grave, we can say that it is probably not younger than the middle of the $3^{\text {rd }}$ century. A more precise date would probably be gained from a coin which was lost.

Belt-buckles of this shape indicate that their owners were related with the army. Since we are dealing with a unique find on our territory, we presume that its owner, burried in the grave nr. G1-956 of the "Više grobalja" necropolis, brought it from the territory of the Raetian limes. According to the number of finds from the Raetian limes, it is considered the place of its origin, which is also confirmed by a find of a mould for casting buttons with spherical head from Regensburg. Without exceptions, such buttons were parts of sets along with this type of belt-buckles. ${ }^{9}$

7 Fischer 1988, 176-179, Abb 4, 5; Abb 6, 5 .

8 Genčeva 2012 A, 107.

9 Fischer 1988, 188. 


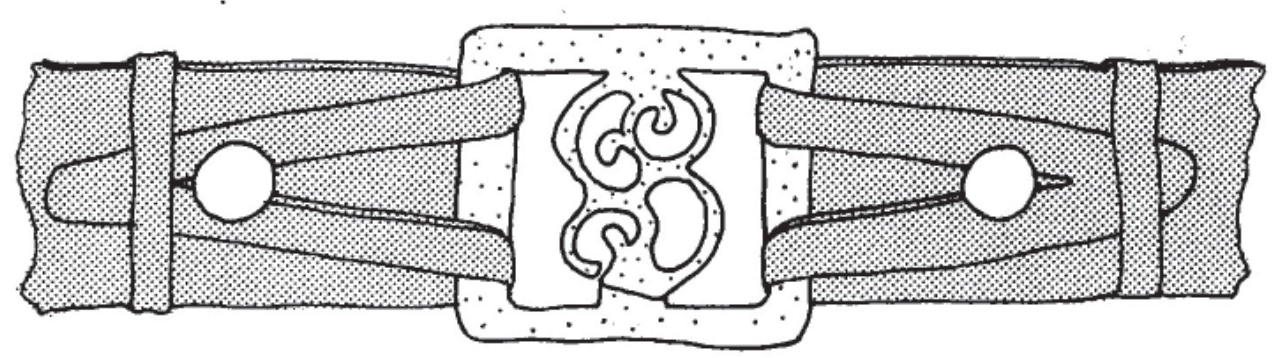

Figure 2. Way of fitting the belt-set.

\section{BIBLIOGRAPHY}

\section{Boube-Piccot 1994}

C. Boube-Piccot, Les bronzes antiques du Maroc

IV: L'équipement militaire et l'armemen, Paris 1994.

\section{Fischer 1988}

T. Fischer, Zur Römischen Officierausrüstung im 3. Jahrhundert n. Ch., Bayerische Vorgeschichtsblätter 53, 167-190.

\section{Genčeva 2012}

A - E. Genčeva, Roman Military Equpment from the Bulgarian Lands (I-III c. AD), The Lower Danube Roman Limes (I-VI c. AD), Sofia 2012.

\section{Oldenstein 1976}

J. Oldenstein, Zur Ausrüstung römischer Auxiliareinheiten, Bericht der Römisch-Germanischen Kommission des Deutschen Archäologischen Instituts 57 (1976), Frankfurt 1977.

\section{Petculescu 1995}

L. Petculescu, Military Equipment Graves in Roman Dacia, Journal of Roman Military Equipment Studies 6, 1995, 105-145.

\section{Schnurbein 1977}

S. Schnurbein, Das römische Gräberfeld von Regensburg, München 1977.

\section{REZIME \\ NALAZ JEDNOG REĐEG TIPA RIMSKIH POJASNIH GARNITURA NA PROSTORU SRBIJE}

U grobu kremiranog pokojnika broj G1956 viminacijumske nekropole „Više grobalja“ pronađena je pojasna garnitura sa kopčom kvadratnog oblika koja nema analogije na teritoriji Srbije. Garnituru upotpunjuje jedno dugme sa kalotastom glavom i pločastom stopom. Slične garniture su nalažene najčešće duž limesa širom rimskog carstva, što ukazuje da su njihovi najčešći konzumenti bili vojnici. Na osnovu većeg broja nalaza iz Regensburga treba pretpostaviti da je matično područje garnitura ovog tipa bilo upravo područje recijskog limesa što potvrđuje i nalaz kalupa za livenje dugmadi sa kalotastom glavom iz ovog grada. Shodno tome treba zaključiti da je garnitura u naše krajeve dospela prilikom veksilacija vojnih jedinica sa prostora recijskog limesa. Garniture ovog tipa treba vremenski opredeliti pre svega u period od kraja II pa do kraja druge trećine III veka, mada treba pomenuti i donekle slične luksuzne garniture iz Budimpešte i Silistre koje su datovane u kraj III veka. 